\title{
Welfare protection of the animal-athlete in the sports company in light of the evolution of the legal regime for animals
}

\author{
Marine Lercier \\ Research Staff in Training (PIF) and Ph. D. Candidate, Faculty of Law, Autonomous University of \\ Barcelona \\ ICALP Member. Alumni of the Master's in Animal Law and Society (6th edition)
}

Received: January 2019

Accepted: January 2019

Recommended citation. LERCIER, M., Welfare protection of the animal-athlete in the sports company in light of the evolution of the legal regime for animals, dA. Derecho Animal (Forum of Animal Law Studies) 10/1 (2019) - DOI https://doi.org/10.5565/rev/da.404

\begin{abstract}
Neither Labor Law nor Civil Law has yet drawn the legal consequences of the existence of labor relations that unite animals and man. There are no rules protecting animals at work, while their participation in multiple human activities is unequivocal. The use of horses in sports and tourism generates wealth, while the services they provide save or improve lives. While it is easy to "work with animals", it is true that it is never explicitly recognized that animals "work with people". Why? Because animals are subject to the legal regime of property. The case of an animal as versatile as the horse leads us to believe that after having inspired numerous animal protection laws, his participation in society through work could be the first to be recognized. A service provider, transporter, plow, therapist, athlete... he has many roles and is recruited according to his personal skills and physical, intellectual or emotional abilities that make him unique. The social fact that animal labor represents prompts us to claim the specific protection of animals in this context, in light of the emergence of their fundamental right to welfare and, therefore, not to be mistreated. Being well treated in the workplace should be considered as a right of the working population, not as a specific human right. Likewise, the protection and monitoring of the health of the sportsperson must be an imperative that goes beyond the species to which the athlete belongs. This contribution was presented during the Symposium organized by the ADDCDA (Association des Doctorants et Docteurs du Centre de Droit des Affaires) on 11 October 2018 at the University of Toulouse 1 Capitole, on the theme of Sport and Business Law. It is part of the DER2015-69314-P project financed by MINECO, on the legal status of animals.
\end{abstract}

Keywords: legal protection of animals; equine welfare; horses; animal work; animal welfare in sports; equine polyvalence; equine law; fundamental right to welfare; human-animal collaboration; animal rights; social rights; sports enterprises; animal competitions; business law; sports law; animal law; labor law; colloquium; Toulouse.

Resumen - Protección del bienestar del animal-atleta en la empresa deportiva a la luz de la evolución del estatuto jurídico de los animales.

Ni el Derecho del Trabajo ni el Derecho Civil han extraído todavía las consecuencias jurídicas de la existencia de relaciones laborales que unen a los animales y al hombre. No existen normas para la protección de los animales en el trabajo, mientras que su participación en múltiples actividades humanas es inequívoca. El uso de caballos en el deporte y el turismo genera riqueza, mientras que los servicios que 
prestan salvan o mejoran vidas. Si bien es fácil "trabajar con animales", es cierto que nunca se reconoce explícitamente que los animales "trabajan con personas". ¿Por qué? Porque los animales están sujetos al régimen jurídico de la propiedad. El caso de un animal tan versátil como el caballo, nos lleva a asumir que después de haber inspirado numerosas leyes de protección animal, su participación en la sociedad a través del trabajo podría ser la primera en ser reconocida. Prestador de servicios, transportista, arador, terapeuta, deportista... desempeña muchos papeles y es reclutado de acuerdo a sus competencias personales y habilidades físicas o intelectuales que lo hacen único. El hecho social que representa el trabajo animal nos lleva a reivindicar la protección específica de los animales en este contexto, debido a la emergencia de su derecho fundamental al bienestar y, por eso, a no ser maltratado. Ser bien tratado en el trabajo es un derecho de la población trabajadora, no un derecho humano específico. Análogamente, la protección y vigilancia de la salud del deportista debe ser un imperativo que vaya más allá de la especie a la que pertenece el deportista. Esta ponencia fue presentada en el Coloquio organizado por la ADDCDA (Association des Doctorants et Docteurs du Centre de Droit des Affaires) el 11 de octubre de 2018 en la Universidad de Toulouse 1 Capitole, sobre el tema del Deporte y el Derecho Empresarial. Se enmarca en el proyecto DER2015-69314-P financiado por el MINECO, sobre el estatuto jurídico de los animales.

Palabras clave: protección jurídica de los animales; bienestar equino; caballos; trabajo animal; bienestar de los animales en el deporte; polivalencia equina; derecho equino; derecho fundamental al bienestar; colaboración humano-animal; derechos de los animales; derechos sociales; empresas deportivas; competiciones con animales; derecho empresarial; derecho del deporte; derecho animal; derecho laboral; coloquio; Toulouse.

\section{Summary}
Abstract
Resumen
Introduction
1. Animal law and animal welfare
2. Animal welfare and profit in the sports industry
3. Animal protection in the French sports industry
4. The legal status of animals in the French sports business
Conclusion
Bibliography

\section{Introduction}

The betting on horse races generates around $€ 10$ billion in revenue each year ${ }^{1}$. The participation of non-human athletes in the company's lucrative activity raises important questions, including financial ones, because the animal factor is missing from the equation. As a gathering of the rules applicable to animals, Animal Law is likely to cover both sporting and entrepreneurial matters, bearing in mind that the organization and conduct of sports events are subject to the regulations of federations at the international, European and national levels. In addition to the application of protection standards based on the animal athlete's special vulnerability, and in view of the increased risk of doping, the animal's key contribution calls for a reform of its legal status and the promotion of the reallocation of a percentage of the profits generated by the sports industry using animals to their protection.

Animals used for economic purposes in the context of sporting activities would fall within the category of the company's non-human assets and would benefit from the special protection of the legal regime of sportspersons. Rights arising from their participation in a human activity would be recognized,

\footnotetext{
${ }^{1}$ According to PMU activity data collected by the Gaming Observatory over the period 2007-2017.

Observatoire des jeux (2018). Données d'activité Pari Mutuel Urbain (PMU). [Online] Le portail des ministères économiques et financiers, available at: https://www.economie.gouv.fr/observatoire-des-jeux/donnees-dactivite-pari-mutuel-urbain-pmu [Accessed 10 Dec. 2018].

60 Derecho Animal. Forum of Animal Law Studies, vol. 10/1
} 
such as the right to subsistence, health and dignified retirement, the embryos of an Animal Labor Law based on the central notion of a fundamental right to welfare. Combining Business Law, Labor Law, Sports Law, and Animal Law, 'Equine Law' ${ }^{2}$ will be our thread, the legal framework for the use of horses in sporting events being the most complete to this date ${ }^{3}$. The aim is to demonstrate animals' legitimate claim to worker status when a link of subordination unites them to man, including the non-human athlete, and the timeliness to grant legal personhood at least to domestic animals in France, a prerequisite for the exercise of any animal right in their participation in human activities.

\section{Animal Law and Animal Welfare}

The importance of animals in society is reflected in their consideration by the Law. Claims have emerged in response to a rise in information about the animal condition, in the context of growing compassion due to scientific discoveries, which have brought man back to Nature and the Earth. Understanding that animal life is conscious is the basis for building a legal system for the welfare of animals under human control.

\subsection{Animal Law}

At both the European and international level, there are no binding standards governing the use of animals in sports, although the animal health regulations governing the movement of animals in the European Union and the obligation to identify and register domestic animals are of general application. To date, there is still no international agreement of general scope for the protection of animal welfare or specific agreement for the protection of animals in the practice of sport or at the time of their use in the workplace.

In France, the first Animal Code, published in 2018 by LexisNexis under the direction of Dr. Marguénaud and in partnership with the French renowned Foundation ' 30 Millions d'Amis', is a collection of all the animal-related regulations, over 1000 pages containing the provisions from 7 official codes and the most relevant case law ${ }^{4}$. Three main rules are worth emphasizing: animals recognized as living beings endowed with sentience (L515-14 of the French Civil Code); the sanction of serious abuse and acts of cruelty ( 2 years' imprisonment and a fine of $€ 30,000$, L521-1 of the French Criminal Code ${ }^{5}$ ); and the obligation to keep domestic animals in conditions that are consistent with the biological requirements of their species, because of their sentient nature (L214-1 of the French Rural Code).

In France, legal disputes in the field of Equine Law abound particularly in sales law and could be prompted to change their legal basis for two reasons. On the one hand, if the necessary consequences are drawn from the extraction of animals from the category of things covered by such regulations ${ }^{6}$, the application of any such rules should be excluded. On the other hand, a 'tailor-made' and special regime governing the sale of domestic animals, although imperfect, exists and shall thus prevail. Despite that, legal guarantee of conformity ${ }^{7}$ and guarantee against hidden $\operatorname{defects}^{8}$, that are characteristic of trade in goods, are

\footnotetext{
${ }^{2}$ Equine law could be defined as the grouping of all the rules of law that apply specifically to equestrian activities, whether for leisure or for profit, and more generally as the set of rules that govern the use of equine animals by humans in society.

${ }^{3}$ In a non-exhaustive manner, the author refers to the standards of the French Sport Code and those contained within the French Codes of Trot and Gallop Races, but also the regulations contained within European horse races Codes; the provisions contained within the agreements of the European Trot Federation (UET) and the International Trot Racing Agreement; the regulations of the International Equestrian Federation (FEI) and its national federations; as they offer the most advanced framework for the protection of animals used in sport.

Code du Sport, Consolidated version as of November 30, 2018. Version as in force on December 10, 2018, available at: https://www.legifrance.gouv.fr/affichCode.do?cidTexte=LEGITEXT000006071318 [Accessed 10 Dec. 2018].

Bulletin de la Société d'Encouragement à l'Élevage du Cheval Français. (2018) Règlement de la Société d'Encouragement à l'Élevage du Cheval Français formant le Code des Courses au Trot. Le Trot, available at : https://pro.letrot.com/siteletrotws/publication?type=CODECOURSE [Accessed 10 Dec. 2018].

France Galop. (2018) Code des Courses au Galop, available at: http://www.france-galop.com/sites/default/files/18code09c.pdf [Accessed 10 Dec. 2018].

${ }^{4}$ Code de l'animal, Sous la direction de J.P. Marguénaud et de J. Leroy, LexisNexis, 1re édition, 2018, ISBN : 978-2-7110-2653-1, $1058 \mathrm{p}$

5 Code Pénal. Consolidated version as of November 25, 2018. Version as in force on December 10, 2018, available at: https://www.legifrance.gouv.fr/affichCode.do?cidTexte=LEGITEXT000006070719 [Accessed 10 Dec. 2018].

${ }^{6}$ As, according to Article 1582 of the French Civil Code, 'The sale is an agreement by which one undertakes to deliver a thing, and the other to pay for it.'

Code civil. Consolidated version as of October 1, 2018. Version as in force on December 10, 2018, available at: https://www.legifrance.gouv.fr/affichCode.do?cidTexte=LEGITEXT000006070721 [Accessed 10 Dec. 2018].

${ }^{7}$ According to Article L217-4 of the French Consumer Code, 'The seller delivers a good in conformity with the contract and is liable for any lack of conformity existing at the time of delivery. He shall also be liable for defects in conformity resulting from packaging, assembly instructions or installation where the latter has been charged to him by the contract or has been carried out
} 
regularly invoked in place of that of a critical flaw as required by Article L213-1 of the French Rural Code concerning the action in guarantee in sales or trade in domestic animals. This constitutes an anomaly.

\subsection{The welfare of animals used in human activities}

The World Organization for Animal Health (OIE) offers a basic definition of animal welfare ${ }^{9}$, while scientific discoveries are flourishing to highlight the concepts of 'Umwelt' and 'Innenwelt' developed by Jakob von Uexküll, designating the world outside to and within the animal ${ }^{10}$, according to which, to understand animals, one must not see things in them but subjects.

Welfare involves not only physical well-being but also mental well-being. Obstacles to welfare may consist of pain, stress, fear, deprivation, distress; the frequency, duration, and intensity of these sensations will determine the impact on the animal. Welfare is subjective, as each animal is unique - it is felt by the individual - and varies according to his or her character and personal preferences. To go beyond the physical protection of the animal to encompass its emotional state is to make the fundamental difference between the mere survival and the quality of life of the animal.

It has, therefore, become necessary to protect the physical and psychological integrity of domestic animals used by humans ${ }^{11}$, at last, recognized as living beings endowed with sentience, no longer as machines equipped with mechanical reflexes. Welfare, in fact, plays a key role in athletic performance, to such an extent that beyond the ethical and legal foundations of its promotion, sports companies have a financial interest in optimizing it.

\subsection{The welfare of racehorses}

There is extensive research in equine welfare to inform the formulation of guidelines and standards, due to the historical prevalence of horse use by man and equine versatility. Horses, due to their selection and natural predisposition as a 'prey' species, are very sensitive to stress ${ }^{12}$. Beyond its unpleasant nature, stress is harmful to the immune system and weakens the animal that is subjected to it. Domestic horses are subject to chronic, potentially work-related stress, which can cause many behavioral disorders. Depression in horses has even been systematized by a team of researchers as the 'animal model of depression' ${ }^{13}$.

Horses are brought into training very early, in order to select the very best and bring them to the highest level. Overtraining syndrome has been described in athletes since the 1970s as a 'performance degradation in spite of continued training ${ }^{14}$. Once this state of exhaustion has been reached, a decrease in the training load becomes ineffective, and only a total and long rest can allow the athlete, human or animal, to recover ${ }^{15}$. In order not to compromise either their welfare or their career by underperforming, this must be

under his responsibility.'

Code de la Consommation, Consolidated version as of November 25, 2018, available at: https://www.legifrance.gouv.fr/affichCode.do?cidTexte=LEGITEXT000006069565 [Accessed 10 Dec. 2018].

${ }^{8}$ According to Article 1641 of the French Civil Code, 'The seller is bound by the warranty on account of hidden defects in the thing sold which make it unfit for the use for which it is intended, or which reduce this use so much that the buyer would not have acquired it, or would have given only a lower price, if he had known them.'

${ }^{9}$ According to the OIE Terrestrial Code, animal welfare 'refers to the physical and mental condition of an animal in relation to the conditions in which it lives and dies.'

It refers to the five main principles set out by the Farm Animal Welfare Council (FAWC): do not suffer from hunger and thirst; do not suffer from physical and thermal stress; be free from pain, injury and disease; have the opportunity to express the normal behavior of one's species; do not experience fear and distress.

World Organization for Animal Health (OIE). Terrestrial Animal Health Code, Twenty-seventh Edition, 2018, Volume I, ISBN $978-$ 92-95108-61-5, available at: http://www.oie.int/en/standard-setting/terrestrial-code/access-online/ [Accessed 10 Dec. 2018].

${ }^{10}$ VON UEXKÜLL J.., Mondes animaux et monde humain, suivi de Théorie de la signification (Paris 1965)

${ }^{11}$ Let us remember wild animals remain excluded from this protection, despite their legal status as sentient beings derived from Article L515-14 of the French Civil Code.

12 The stress of these horses has several sources: cold or heat, light or darkness, social isolation or the introduction of a new individual into the group, a new diet or even the anticipation of events that can be aversive, such as a race. All changes, especially if they are sudden and unpredictable, can disturb the horse, especially if they are repeated and create the impression that it does not control its environment and is in a vulnerable situation because it cannot escape the perception of danger, which is very destabilizing for a 'prey' species.

${ }^{13}$ FUREIX C. et al., Investigating anhedonia in a non-conventional species: Do some riding horses Equus caballus display symptoms of depression?, in Applied Animal Behaviour Science 162 (2015) 26-36

FUREIX C., JEGO P., HENRY S., LANSADE L., HAUSBERGER M., Towards an Ethological Animal Model of Depression? A Study on Horses, in PLoS ONE 7(6) (2012) https://doi:10.1371/journal.pone.0039280[Accessed 10 Dec. 2018].

${ }^{14}$ LE GAL, S., Surentraînement du cheval: quel peut être l'apport du suivi de la leptinémie? Thèse d'exercice, Médecine vétérinaire, Ecole Nationale Vétérinaire de Toulouse - ENVT (2012) p12

${ }^{15}$ This condition consists of a feeling of fatigue and a decrease in performance, accompanied by physiological and psychological 62 Derecho Animal. Forum of Animal Law Studies, vol. 10/1 
avoided by managing time and workload in a way that respects the animal's physical and psychological limits.

The quality of handling and interaction with humans from an early age is crucial throughout the animal's life. Force and violence are to be avoided, beyond their dubious morality, as these assaults have such dire effects on the animal's quality of life and on the quality of its relationship with humans, which is then based on fear.

Professional education requires particular attention, given the risk that inexperienced or unsupervised staff may resort to violence and intimidation, punish or take revenge on the animal, use equipment and methods that are increasingly burdensome and painful for the animal and cause unjustified suffering. The majority of obstacles to the welfare of domestic animals are imputable to the people in charge of ensuring their welfare and can be easily corrected.

\section{Animal welfare and profit in the sports industry}

From the Latin 'stringere', stress must be tackled in animals in the sports business, because, etymologically, it 'makes them stiff', which cannot be profitable. However, research on the welfare of animals that work and the stress that this can cause them remains desperately blank.

\subsection{Animal welfare and athletic performance}

The quality of the athlete's performance is tied, in addition to the obvious relevance of an optimal physical condition, to his or her 'mental'. Many studies have pointed out the negative effects of psychological distress on the performance of the animal in competition, and the positive effects of improving the animal's well-being. Welfare comes as a prerequisite for the development of the athlete's full potential, for which the company has 'chosen' him or her ${ }^{16}$, and therefore a guarantee of profitability.

These two ambitions, welfare and profit, are not irreconcilable. On the contrary, they are interdependent in the sports business, for which investing in animal welfare provides a competitive advantage. Although it is difficult to quantify the benefits of animal welfare on the sports company's financial result, the costs of malaise are very clear: accidents, injuries, diseases, veterinary expenses, breaks, underperformance... or even the end of the promising athlete's career. All this has a negative price for the company.

\subsection{Animal welfare and Corporate Social Responsibility (CSR)}

The change in the legal status of animals is expected to affect the regulation of sports companies that use animals. In France, professionals in the horse industry signed the Charter for Equine Welfare in 2016, applicable to all equines regardless of their use and age and based on 8 fundamental principles ${ }^{17}$. Not only is it important to respect the biological needs and natural behaviors of the animal, fundamental to ensure its welfare; the horse must be comfortable in both mind and body. However, the living conditions of these animals are all too often still characterized by retrograde habits and lack of ethological knowledge that hinder their welfare and performance, such as solitude, inadequate nutrition, lack of space and confinement in the box.

How can these ethical concerns be integrated into economic activity? This is what the concept of Corporate Social Responsibility (CSR) seeks to address. The idea came from the work of American managers in the $1950 \mathrm{~s}^{18}$, according to which if companies also focus on the impact they have on society, they will derive a benefit.

In the present case, beyond enhancing the animal's performance by improving its welfare, which would encourage the company to change its behavior in this direction, the very survival of any sporting

changes, resulting from an imbalance between work and fatigue, training and rest, which prevents the body from recovering.

LE GAL, S., Surentraînement du cheval: quel peut être l'apport du suivi de la leptinémie? Thèse d'exercice, Médecine vétérinaire, Ecole Nationale Vétérinaire de Toulouse - ENVT (2012) p13

It is mainly manifested by a decrease in the time during which the horse can maintain his effort, by weight loss and by a change in behavior (irritability, reluctance to work, disobedience, bites.

TYLER-MCGOWAN C. M., GOLLAND L. C., EVANS D. L., HODGSON D. R., ROSE R. J., Hematological and biochemical responses to training and overtraining, in Equine Veterinarian Journal 30 (1999) 621-625.

16 Or at least, the 'owner' who entrusts it to the coach when the latter has not intervened in this choice.

${ }^{17}$ French Charter for Equine Welfare, signed in Paris on 4 March 2016, available at:

http://www.lafranceagricole.fr/r/Publie/FA/p1/Infographies/Web/2016-03-07/CharteEquins.pdf [Accessed 10 Dec. 2018].

${ }^{18}$ BOWEN H., Social Responsibilities of the Businessman (New York 1953). 
activity involving the participation of animals is decisive in the decision to pursue welfare. Indeed, the use of animals will be accepted as long as the welfare of these animals is deemed acceptable. Without such approval of society, sports businesses that use animals for the competition will disappear.

In the case of the French horse racing industry, due to the provenance of the revenues - horse racing bets - the endorsement of the spectators who finance the industry is inescapable. As the stables are collectively dependent on this supply to the economic circuit through betting, it is up to the mother societies (SECF and France Galop) to carry out a comprehensive strategy of social responsibility.

$\mathrm{ISO}^{19}$, which publishes guides for businesses to assist them in developing their strategy, has not yet issued any such guidance on animal welfare. More research is needed to inform and advise the improvement of animal welfare in the sports business, which entails the acceptance of animal work as a social fact. Yet, the topic of animal welfare has already taken over the fields of food ${ }^{20}$ and fashion ${ }^{21}$.

\subsection{Welfare in the law}

The notion of welfare is enshrined in international human rights instruments designed both to promote them and to protect them. The cornerstone of this conception is found in Article 25 (1) of the Universal Declaration of Human Rights, according to which:

Everyone has the right to a standard of living adequate for the health and well-being of himself and of his family, including food, clothing, housing and medical care and necessary social services, and the right to security in the event of unemployment, sickness, disability, widowhood, old age or other lack of livelihood in circumstances beyond his control. ${ }^{22}$.

Welfare is obviously the legally safeguarded item within this system. Comparing this provision to the standards encompassing the ' 5 fundamental freedoms' of animals identified by the FAWC ${ }^{23}$, we note a twin-track approach to the protection of basic needs for housing, food, thermal comfort, health and shelter from physical and psychological harm, precisely because it threatens the welfare of any sentient living being.

Only a short step forward remains to be taken to predict the escalation of the weight given to the legally protected interest of welfare, to the point of assuming that there is not much time left before its admission as an animal right claim to go beyond man's simple duty in his relationship with the animal.

\section{Animal protection in the French sports industry}

The extraordinary destiny of some must not be used as an overarching example to lose sight of the need to protect animal athletes at all stages of their careers, from their selection to their conclusion. Barriers are set so that the race for profit does not have negative outcomes for the animals involved ${ }^{24}$. Particular attention must be paid to giving the animal used in sports the right not to be a champion owing to the precariousness of such an athlete's situation.

\subsection{The protection of domestic animals from abusive human use}

\footnotetext{
${ }^{19}$ The International Organization for Standardization (ISO). See ISO 26000, Social Responsibility, available at https://www.iso.org/fr/iso-26000-social-responsibility.html [Accessed 10 Dec. 2018].

${ }^{20}$ Elior Group, for example, has included animal welfare as a priority in its CSR strategy, the 'Positive Foodprint Plan', in partnership with CIWF and inspired in particular by the 5 freedoms proposed by FAWC, with the objective of eliminating cage eggs by 2025 .

See https://www.eliorgroup.com/fr/elior-group-positive-foodprint-plan [Accessed 10 Dec. 2018].

${ }^{21}$ The fashion industry is the scene of a growing voluntary phase-out of the use of animal fur. Burberry is one of the latest. See 'GB: Burberry renounces fur and the destruction of unsold goods', Fondation 30 Millions d'Amis, 6 September 2018, available at: https://www.30millionsdamis.fr/actualites/article/14462-gb-burberry-renonce-a-la-fourrure-et-a-la-destruction-des-invendus/. [Accessed 10 Dec. 2018].

London Fashion Week, from 14 to 18 September 2018, paraded without animal fur. See 'La Fashion Week de Londres défilera sans fourrure cette année', Madmoizelle, 10 September 2018, available at:

http://www.madmoizelle.com/fashion-week-londres-sans-fourrure-952242 [Accessed 10 Dec. 2018]

22 The United Nations. (1948). Universal Declaration of Human Rights, available at: http://www.un.org/en/udhrbook/pdf/udhr booklet en web.pdf [Accessed 10 Dec. 2018].

${ }^{23}$ Farm Animal Welfare Council (FAWC), created in 1979 as a result of the Brambell report published in December 1965 (HMSO London, ISBN 0108502864 ) and developing the concept of the 5 freedoms outlined in the Brambell report.

See http://webarchive.nationalarchives.gov.uk/20121010012427/http://www.fawc.org.uk/freedoms.htm [Accessed 10 Dec. 2018 ].

${ }^{24} \mathrm{Such}$ as minimum age to avoid harming the young's growth and development, maximum age for participation in competitions, respect of the athlete's physiological rhythms and the prohibition of abusive use.

64 Derecho Animal. Forum of Animal Law Studies, vol. 10/1
} 
It is clear from the French Rural Code that any abusive use of animals is prohibited (L214-3) ${ }^{25}$ and that the basic needs of the animals must be met by the person who is in control of them (L214-1) ${ }^{26}$. The sole provisions implementing this principle of banning the abuse of animals used in human activities and using the terminology of work are found in the French Sports Code with regard to horses, who must be protected from exhaustion in the context of an overall reasoned and responsible use of their resources.

The French Trot and Gallop Racing Codes complete these provisions at the time of the competition, to sanction abuses. However, apart from abuse embodying totally objectionable use, there is no definition of what constitutes 'acceptable use' or 'respectful use' under the law ${ }^{27}$. It is to be regretted that neither the French Labor Code nor the French Rural Code has yet delineated what constitutes animal abuse by imposing a legal work duration, a prohibition of overloading, a mandatory rest, a compulsory health monitoring, a dignified retirement, in other terms the responsibility towards - and not for - the animal.

Labor Law is undergoing reforms to adapt to changes in society, and why not, soon, to the rights of animals at work, since the latter mobilize their physical, intellectual and emotional capacities alongside men. Animals never perceive the results of the profit they generate, whether they are tangible (products of animal origin such as milk, or their offspring that do not in any way belong to them) or less tangible (direct remuneration for their carriage traction, remuneration for their assistance in therapy, allocation of earnings in competition). Realizing that animals - at least domestic animals - contribute to society in many ways, animal protection can be considered to be a new area of Labor Law in the making ${ }^{28}$.

To all intents and purposes, the use of animals by humans in their activities is the object of mutual obligations: obedience to orders, conformation to instructions, execution of tasks requested, performance of behavior learned, docility on the part of the animal; good care, food, shelter, health, comfort, attention on the part of humans. As society tends to rethink its relationship to animals, a law on the protection, subsistence, health, working time limitation, compulsory rest and retirement of working animals is expected to be adopted.

\subsection{The protection of animal athletes against doping}

According to Article L241-2 of the French Sports Code, 'It is prohibited to administer or apply to animals, during competitions and sporting events (...) or with a view to participating in them, substances or processes likely to artificially modify their capacities or to mask the use of substances or processes having this property'. Article L241-5 of the same code sets a penalty of 5 years' imprisonment and a fine of $7500 €$ in the event of an offence or attempted offence under these provisions, while the penalty is six months' imprisonment and a fine of $7500 €$ for being an accomplice in any way ${ }^{29}$.

Under Article L245-6, approved sports federations or the French Anti-Doping Agency may provisionally, temporarily or definitively prohibit the owner or trainer of the animal to which a prohibited substance has been administered or a prohibited process applied from involving that animal in the competitions and sporting events in question. Similarly, at the end of Article L241-7, the owner or trainer is liable to administrative penalties ranging from a temporary or permanent ban on participation in sporting

\footnotetext{
${ }^{25}$ According to Article L214-3 of the French Rural Code, 'It is prohibited to abuse domestic animals as well as wild animals tamed or held in captivity.'

Code rural et de la pêche maritime. Consolidated version as of December 3, 2018. Version as in force on December 10, 2018, available at: https://www.legifrance.gouv.fr/affichCode.do?cidTexte=LEGITEXT000006071367 [Accessed 10 Dec. 2018].

${ }^{26}$ According to Article L214-1 of the French Rural Code, 'Any animal being a sensitive being must be placed by its owner under conditions compatible with the biological requirements of its species.'

${ }^{27}$ Indeed, Article L214-2 of the French Rural Code only provides that 'Every man has the right to keep animals under the conditions defined in Article L. 214-1 and to use them under the conditions provided for in Article L. 214-3, subject to the rights of third parties and the requirements of public health and safety and the provisions of Act No. 76-629 of 10 July 1976 on nature protection.'

${ }^{28}$ It was not until 1841 that child labor was regulated in France by the Law of 22 March 1841 on child labor in manufactures, factories or workshops, known as 'Loi Montalembert', available at: https://travail-emploi.gouv.fr/IMG/pdf/loi 22 mars 1841-2.pdf [Accessed 10 Dec. 2018].

The law, therefore, prohibits the employment of children under 8 years of age and limits the working day to 8 hours for 8-12-yearolds. Unthinkable today, it was a huge step forward at the time in the protection of children. This is only the beginning of a slow (r)evolution of consciousness and the result of a real desire to improve the well-being of children.

${ }_{29}$ According to Article L241-3 of the French Sports Code ' $1{ }^{\circ}$ Facilitate the administration of the substances mentioned in Article L241-2 or encourage their administration, as well as facilitate the application of the procedures mentioned in the same article or encourage their application; $2^{\circ}$ Prescribe, administer, apply, transfer or offer one or more processes or substances mentioned in Article L. 241-2; $3^{\circ}$ Produce, manufacture, import, export, transport, hold or acquire the processes or substances mentioned in Article L. $241-2 ; 4^{\circ}$ Oppose by any means whatsoever the control measures provided for in this Title; $5^{\circ}$ Falsify, destroy or damage any element relating to the control, sample or analysis; $6^{\circ}$ Attempt to violate the prohibitions provided for in this Article.'Additional penalties are also provided for in Article L232-27 of the French Sports Code.
} 
events, to a temporary or permanent ban on direct or indirect participation in the organization or conduct of such events and in training preparatory thereto, as well as a temporary or permanent ban on performing the functions defined in Article L212-1 ${ }^{30}$.

In order to protect the athletes and their well-being, the International Equestrian Federation (FEI) has set up two anti-doping systems known as the 'Clean Sport' program ${ }^{31}$. One is designed for humans, while the other relates to horses, the regulations of which are based on the World Anti-Doping Agency Code ${ }^{32}$. The control of equine doping is governed by the Anti-Doping and Equine Drug Control Regulations, the List of Prohibited Substances and the FEI Veterinary Regulations. The list of prohibited substances is divided into Prohibited Substances ${ }^{33}$ and Controlled Drugs ${ }^{34}$. The European Union of Trotters ${ }^{35}$ and its affiliated National Racing Federations ${ }^{36}$ also establish a list of prohibited substances ${ }^{37}$ and a sanctions regime on the basis of which inspections and controls are carried out ${ }^{38}$.

\subsection{The protection of equids in sport}

While many sports are structured primarily as non-profit associations for recreational purposes, the main concern of the horse racing industry is to generate revenue and maximize profits. The French Sports Code pays particular attention to the rules on the use of equids ${ }^{39}$, while Codes have been issued to regulate horse racing in all European Union countries where these events are taking place.

Such a legislative arsenal supports the vision put forward by the author of this contribution, which is that of the horse's entitlement to acquire legal personality, taking into account the versatility of its uses, in particular its active participation in the economy of society, and the complexity of the legal regime (the most complex of all) devoted to this domestic animal, beyond the arguments traditionally used in support of such a claim, criteria that the horse obviously meets (autonomy, intelligence, affection, community membership, individuality, sentience, etc.). Yet the picture is quite the opposite: horses are a species that is still lacking even framework legislation at European Union level, that would be aimed at regulating their welfare at the various stages of their lives and according to the use that is being made of them.

Regardless, under French law, an emblematic provision, Article A322-128 of the French Sports Code, lays the foundations for regulating the work of equines, which reads 'An equine animal must not be required to perform work for which it is neither fit nor prepared, which could endanger its health and the rider's safety.' Article A322-139 extends further and adds that 'Worn, sick or injured animals, as well as mares in advanced pregnancy, shall not be used' while Article A322-140 lays down certain conditions for the treatment of horses outside what is accurately referred to as their 'working time', using precise and appropriate terminology, by stating that 'It is prohibited to leave tied animals exposed to direct sunlight or bad weather; horses shall not remain saddled and restrained outside working hours'. This combination of provisions of the French Sports Code clearly frames equine work.

A pressing issue with sports horses though is that they are not excluded from the slaughter industry in the absence of a ban on their breeding, trade and slaughter for their meat, even when they are not bred or intended for human consumption in the first place, which is the case with sports horses. This is a twofold concern, first of all, sanitary: the vast majority of animals used in sport, if not all, have received during their

\footnotetext{
${ }^{30}$ Consisting of the training, teaching or supervision of such a sporting activity, a sanction which may be imposed by an approved sports federation or by the French Anti-Doping Agency whose powers and functions are listed in Article L322-5 of the French Sports Code.

${ }^{31}$ See https://inside.fei.org/fei/cleansport [Accessed 10 Dec. 2018].

32 World Anti-doping Code, World Anti-doping Agency, 2015, adopted in 2003 and entered into force in 2004, available at: https://www.wada-ama.org/sites/default/files/resources/files/wada-2015-world-anti-doping-code-fr.pdf [Accessed 10 Dec. 2018 ].

332018 Equine Prohibited Substances List, 2017, available at:

https://inside.fei.org/sites/default/files/2018\%20Equine\%20Prohibited\%20Substances\%20List.pdf [Accessed 10 Dec. 2018 ].

34 FEI Equine Anti-Doping and Controlled Medication Regulations, $2^{\text {nd }}$ edition effective 2018, 2017, available at: https://inside.fei.org/sites/default/files/2108\%20EADCMRs\%20-\%20Effective\%201\%20January\%202018\%20\%20Final\%20Version clean.pdf[Accessed 10 Dec. 2018].

${ }^{35}$ See https://www.uet-trot.eu/fr/ [Accessed 10 Dec. 2018].

${ }^{36}$ Parties to the International Agreement on Trotting Races. International Agreement on Trotting Races, European Trotting Union, 2018 Edition, available at:

https://inapp.org/sites/default/files/NORMATIVA/2018/Comunitaria/UE_Accord_international_sur_les_courses_au trot_UET\%202 018.pdf [Accessed 10 Dec. 2018].

${ }^{37}$ Regarding France, see the list published by the FNCH (Fédération Nationale des Courses Hippiques), available at: http://www.fnch.fr/index.php/controle-des-courses/le-controle-antidopage/liste-des-categories-de-substances-prohibees-et-les-seuils [Accessed 10 Dec. 2018].

${ }^{38}$ Articles 3, 77 and 78, and Annex I of the French Code of Trotting Races; Articles 198, 199, 200 and 201, and Annex 5 of the French Code of Galloping Races.

${ }^{39}$ See Section 4: Establishments open to the public for the use of equids, Articles A322-16 to A322-40 of the French Sports Code.

66 Derecho Animal. Forum of Animal Law Studies, vol. 10/1
} 
lives drug treatments that make them unfit for human consumption, with regard only to known and already prohibited substances, when such (voluntary) declaration has been properly carried out to prohibit the slaughter of these animals for the food chain, while their traceability is often in question; and, of course, ethical, because of the opposition and shame that are legitimately aroused by the decision to send animals for slaughter for the mere reason that they are not or no longer fit to compete, and therefore not as profitable as they should be.

\section{The legal status of animals in the French sports business}

The author of this article questions the validity of subjugating animals to the property regime in situations where they are recruited to bring their physical, intellectual and emotional skills to carry out a specific activity, whether in sport as in the present case or in any other work environment. Indeed, this contradicts their exclusion from the category of things since the reform of the French Civil Code in 2015 and remains on the margins of the scientific and moral progress made by society, in total incompatibility with this archaic conception of the animal and the legal framework it is governed by.

\subsection{The legal status of animals in France: From Lunus ruling to Article L515-14 of the Civil Code}

A founding decision of Animal Law and emblematic for the subject at hand, the Lunus judgment handed down on 16 January 1962 by the Court of Cassation on the basis of civil liability was to rule on the award of damages following the death of a racehorse ${ }^{40}$. On that occasion, the Court qualified the relationship between the racehorse and its owner as one of affection, considering that the death of the horse had caused the latter a moral prejudice, in addition to the material damage resulting from the ownership link.

The judge, aware that at the time 'such damage is only conceivable on the occasion of the loss of a loved one, and that there is nothing in common between the disturbance caused by the disappearance of a person $^{41}$ and that of an animal', nevertheless decided that 'regardless of the material damage it causes, the death of an animal may be for its owner the cause of subjective and emotional damage likely to give rise to compensation' because he was 'dearly bound to it'.

One detail of great importance seems to have been missed by the doctrine and argues in favor of the collaboration and work relation that unites men and animals, outside from the property framework. The racehorse trainer, who had been denied any right to claim compensation for an alleged material prejudice as the animal did not belong to him and because compensation for the loss of the chance to win was not admissible, was nonetheless awarded damages on the basis of the moral prejudice he had suffered due to the loss of an animal to which he was bound, although no link of ownership ever united them. By doing so, the judge implicitly compensated the moral damage suffered because of the loss of a strong, affectionate bond built on the collaboration and work relationship that united the trainer to the racehorse.

This decision is groundbreaking for two major reasons. The first reason is that the present case did not deal with the loss of a companion animal but involved the death of a horse, still to this date considered a livestock animal, for which one could have expected the strict characterization of a material damage and the award of damages up to the pure market value of the racehorse. However, the categorization of the animal did not in this case presuppose the existence or rejection of an affectionate bond. The second reason, which is even more obvious, is that moral prejudice was conceived not only in the context of the loss of a human person exclusively but as well in the unique circumstance of the existence of a family relationship, further excluding the award of damages to compensate for the moral prejudice of a concubine. One may wonder if the animal was not, already at the time, in a situation of 'legal levitation' according to Dr. Marguénaud's expression ${ }^{42}-$ not exactly a thing, not at all a person?

The contribution of this judgment is of considerable importance and has gone far beyond the scope of Animal Law alone. Thus, compensation for moral pain has become widespread in an effort to transform the Law of Civil Liability, going so far as to concede that a corporate body may, in turn, suffer moral damage. Arguing from this strong malleability of the Law and the flexibility of its concepts that bend to the needs of its beneficiaries, the potential for reforming the laws that surround our relationship with animals and their

\footnotetext{
${ }^{40}$ Lunus, a racehorse, was electrocuted due to the negligence of the organizers of the sporting event (the horseracing society) and his trainer, after grabbing a bulb left within his reach in a box lent by the racetrack on which he was to compete in a race. Court of Cassation, Civil Division 1, of 16 January 1962, Published in the bulletin, available at: https://www.legifrance.gouv.fr/affichJuriJudi.do?idTexte=JURITEXT00000006960299 [Accessed 10 Dec. 2018].

${ }^{41}$ Implied, 'human'.

${ }^{42}$ Read the interview with Dr. Jean-Pierre Marguénaud, 'Le statut de l'animal est en lévitation juridique', Terre d'Actu, November 18, 2016, available at:

http://www.terredactu.com/entretien-jean-pierre-marguenaud.html [Accessed 10 Dec. 2018].
} 
place in society is endless. Recognizing the animal as a victim of direct and personal injury would be a key step in giving animals the right to obtain compensation and would make it possible to give full meaning to the sanction and greater utility to the conviction of their abusers.

The recognition by the French Civil Code of animal sentience came to consecrate, certainly the ability of man to cause an animal to suffer, because it is sentient, through infringements of its physical and psychological integrity, but also, which is what is important in the matter before us, the inclination resulting from this sensitivity to forge relationships of affection and collaboration with man, whatever the functional category where certain classes of animals are to be classified, as both farm animals and pets are sentient, whatever the existence of an ownership or guardianship relation, and regardless of their species ${ }^{43}$.

As the legal status of animals is changing, so too must their legal regime. Subjecting animals for longer to the property regime - except where special laws have gradually replaced general law, taking precedence over it - without valuing the multitude and richness of the links that unite them to humans through their consideration by Law, undermines their protection and proves incapable of guaranteeing their nascent Right to Welfare and their interest to enjoying a state of welfare already legally protected by limiting the potential for protection.

The attribution of market value to domestic animals in human activities and not, as is the case for human persons, to their own labor force, skills and time, leaves them vulnerable. Shifting the focus to the reciprocal obligations and mutual interests that unite men and animals in labor relations seems to be the way to go. All the necessary ingredients are gathered to give legal personality to working animals, especially in the case of athletes who generate quantifiable benefits in the form of financial allocations. A more comprehensive study of how the benefit thus generated could potentially be used to improve their welfare and protect them from treatment and disposition that would run counter to their individual interests and disregard their interest in living well - that is, as property - is necessary.

\subsection{The legal status of animals in the workplace}

It is generally assumed that animals do not work, and it is incorrectly presumed that one can theorize labor relations on the one hand, and human-animal relationships on the other, without ever considering Animal Labor or the participation of animals in society. Only a few researchers investigate animal work and studies are missing on the specificity of this recourse to the capacities of living beings of different species than ours. The idea that work is an exclusively human social relationship must be challenged.

\subsubsection{Human-animal collaboration}

Animals do not work only by, with and for humans. Many are the cases of complex division of labor to meet the needs of the community: bees, beavers, termites, ants... So many social facts ignored or deliberately denied by humanity, convinced for the most part of its history that only man was capable of innovating to solve problems. When the capacities of certain animals are used by humans, these animals are involved in the production of goods and the creation of wealth, provide useful services, participate in the life of the community to contribute to the overarching goal of any society, which is to improve the overall welfare of all and each of its members.

Yet, according to Friedmann and Naville ${ }^{44}$, the term 'work' should not be used to 'designate dehumanized and animal operations', because the term would necessarily imply a subjectivity and a form of free will that is presumptuously purely human. Contrary to this myth of work being man's characteristic, the animale laborans described by Arendt ${ }^{45}$, interchangeable as a member of his species and devoid of personality, suggests a reification of man that loses all sacredness in the work. From one extreme to the other, it is a pitfall that is not sustainable. If the human worker is not a thing, the animal is not a tool either.

Somewhat fortunately, researchers such as Kymlicka and Donaldson are addressing, from a political philosophy perspective, the dynamics of an interspecies society, of which animals and humans are members,

\footnotetext{
${ }^{43}$ Deplorable is the fact that the equal sentience of wild animals does not give rise to a similar regime to that of domestic animals under Criminal Law. Wild animals, which do not belong to humans or to themselves, but only to a 'whole' in Nature, are not considered as individuals worthy of protection, except in the particular case in which a minimum number of individuals must be preserved to conserve the species, entitling them to a form of protection of endangered animal life, mostly to the benefit of humans in their interest to preserve a certain amount of biodiversity.

${ }^{44}$ FRIEDMANN G., NAVILLE P., Traité de sociologie du travail (Paris 1962), p17

${ }^{45}$ SAAVEDRA J., Hannah Arendt y el "animal laborans". Reflexiones en torno a la condición humana postmoderna, in Nómadas. Revista Crítica de Ciencias Sociales y Jurídicas 29/1 (2011) http://dx.doi.org/10.5209/rev NOMA.2011.v29.n1.267 [Accessed 10 Dec. 2018].
} 
against the dominant ideology that animals are resources that can be used for the sole benefit of man ${ }^{46}$. Indeed, once their status as living beings has been reaffirmed, animals (at least those domesticated by humans) can no longer be considered as outsiders on the margins of society, because they live among - and with - us. Animals indeed entered into society with the man by means of domestication, both uniting their labor forces and joining their efforts in their common, greater interest for welfare.

Animals, therefore, are not strangers to human society as some claim, but on the contrary, have come to play a pivotal role in many activities, if not the majority of them, if we consider the use of animals for food, research, leisure... The historical processes of domestication mark the birth of animal collaboration with humans, which we will refer to as Animal Labor ${ }^{47}$. Starting from this form of cooperation driven by shared interests, members of some species have come to form an emotional bond with the man to make their way into his family.

By domesticating them and forming such affective relations, we have invited certain species to form part of society, although its current face since the end of the 20th century and the beginning of the 21 st century, particularly in the agri-food and medical-pharmaceutical industries, leads us to question the legitimacy, actual content and appropriateness of this pact between men and domestic animals, to the extent of asking what has become of this link in an activity such as livestock breeding with age-old traditions.

Animals have been engaged in many occupations through the ages. From 'farmers' and 'carriers', they have turned into genuine 'personal assistants', 'life helpers' or even 'therapists'. Their activity, initially agricultural, then industrial, expanded to the tertiary sector. The selection of the most docile individuals for reproduction has been coupled with vocational training for the pursuit of a specific profession. No one could deny that the security or police dog is taught the basics of the job, nor that the trotter horse is trained to be the most efficient physically and mentally, without ever stepping 'out of line' ${ }^{48}$.

Animals, subordinated to man, respect the customs to which they have been socialized. Domestic animals used in human activities have a good understanding of what is expected of them and comply with the instructions. A work routine ensues: the horse that arrives at the racetrack to compete in a race can start to stress for the competition or be eager to 'fight it off'. In Zola's oeuvre, Germinal, the horse named Bataille, after 10 years of loyal and painful service at the bottom of the mine, counted his rounds and refused to do another one once the prescribed number of trips had been made; he was then taken to the feeder ${ }^{49}$.

\subsubsection{The protection of animals at work}

If one investigates the place of animals in the company, the findings are clear. Animal work does not exist, and the only online results relate to human well-being. This is what 'animals at work' refers to ${ }^{50}$. Quite the opposite, the angle discussed here apprehends animals, not as companions that would improve the well-being of the human employee ${ }^{51}$, but rather as authentic collaborators.

No provisions are laid down in the French Labor Code for the protection of animals, although there is no doubt their talents are being used by companies. Legally speaking, animals do not belong to the company's workforce. They are still subject to the property regime, since no special law has been adopted to further regulate their status ${ }^{52}$. They are not individuals participating in the activity, although they are recruited because of capacities and skills that make them 'unique', in the sense recently endorsed by the Delgado decision with respect to companion animals ${ }^{53}$.

Hence, in the words of Jocelyne Porcher, 'work is the one most absent from the animal issue ${ }^{54}$.

\footnotetext{
${ }^{46}$ See, in particular, Zoopolis and the many articles published by the couple on the topic. DONALDSON, S., KYMLICKA, W., Zoopolis: A political theory of animal rights (Oxford 2011).

${ }^{47}$ The earliest form dates back to the domestication of the wolf that joins man in hunting, to become the guardian of his home, to the point of reaching the very heart of his home; as did the cat, a farm companion useful in eliminating rodents that threaten the grain, that found its place within the family.

${ }^{48}$ A trotter who takes a certain number of strides at speeds other than trotting during a race may be penalized by disqualification and is therefore prohibited from claiming a position granting him a financial allowance: he is therefore taught to stay in the trot from the very first moments of his training.

${ }^{49}$ ZOLA E., Germinal (Paris 1885) pp 84-86

50 'Chiens et chats dans l'open space', L'Express Entreprise, by Isabelle Hennebelle, published on June 10th, 2018, available at: https://lentreprise.lexpress.fr/des-chiens-et-des-chats-dans-l-open-space_2010594.html [Accessed 10 Dec. 2018].

51 'Pets at work ou les bienfaits des animaux au bureau', GA Smart Building, available at: https://www.ga.fr/newsroom/pets-work-ou-les-bienfaits-des-animaux-au-bureau [Accessed 10 Dec. 2018].

52 Article L515-14 of the Civil Code reads 'Animals are living beings endowed with sensitivity. Notwithstanding the laws that protect them, animals are subject to the property regime.'

53 'Delgado' judgment, Court of Cassation, Civil Chamber 1, 9 December 2015, 14-25.910, Published in the bulletin.

${ }^{54}$ Read Jocelyne Porcher's Interview by Le Monde, 'Les animaux consentent-ils à travailler ?' of 7 January 2018, available at: https://www.lemonde.fr/idees/article/2018/01/07/les-animaux-consentent-ils-a-travailler 5238389 $3232 . h t m l$ [Accessed 10 Dec. 2018].
} 
Although one can easily 'work with animals', there is never explicit recognition that 'animals work with people'. There is only one reference to Animal Labor to be found in Article L211-10 of the French Labor Code, which reads 'Silkworms cannot be seized during their work. The same applies to the mulberry leaves they need.' This provision can hardly be considered a standard of protection for silkworms at work. Whereas the wording of the article presumes a certain seriousness with regard to forbidding the annoyance of silkworms by removing any mulberry leaf from them, it is a safe guess that the only beneficiary of this requirement is the man. This provision is anecdotal, and the animal does not enjoy any significant protection.

A problem subsists: what is produced by the animal as a result of its subordination to man never belongs to it. Its trade-off is subsistence, or even very often mere survival, in the absence of effective enforcement of animal protection standards. This could change though if the sanctions against abuse provided for in Article L214-3 of the Rural Code, whether the animal is used for work or kept as a companion, were to be strengthened. Additionally, protection associations shall be able to file a civil suit under a necessary amendment to Article 2-13 of the Code of Criminal Procedure ${ }^{55}$. Either way, providing the animal with the very least necessary so that it may continue to provide its power appears inadequate for the purpose of an encompassing protection throughout its life, regarding the risk animals run of being treated as something that can be disposed of once their usefulness or profitability is extinguished.

Liberating animals does not necessarily mean putting an end to the millenary relationships that unite domestic animals with humans. It is about empowering them to achieve more than mere survival in return for their participation. It is about enabling them to live a life consistent with their animality and in harmony with their individuality. It is about treating them as the living beings they are - and not as something which represents the final and most enduring objective of animal protection laws from the very beginning. Man must admit and respect the boundaries of animals, otherwise, the communication will be severed, and a definitive term put to these exchanges ${ }^{56}$.

Not to be mistreated is a fundamental right. To be well treated at work is a right of the worker, not a right specific to the human being. It is necessary to follow through on the rationale behind animal protection laws that first emerged, as it should be recalled, in response to the most painful and obvious forms of animal work for society, a society that could no longer bear to see carriage horses suffering to the point of exhaustion on the streets in the 19th century ${ }^{57}$.

Hence the issue is no longer asking whether it is necessary to be a legal person, and of what type (natural or juridical, human or animal) to be granted protection, but to finally decide under which circumstances an animal may be provided with legal personality, an insurmountable prerequisite for the exercise of rights and in particular for the enjoyment of certain rights at work. The 1807 Civil Code did not recognize the company as a legal entity endowed with legal capacity, although the courts granted $\mathrm{it}^{58}$. Juridical personality is essentially nothing more than a legal mechanism that is based not on the quality of human being, but on the imperative of being represented because of autonomous interests that are not necessarily the same as those of the person acting in the name and in the interest of the juristic entity ${ }^{59}$. If a company - a fictitious, non-sensitive organism - has been granted legal personality for practical reasons, what technical obstacle would prevent its attribution to animals, as sentient individual beings?

\subsection{The legal status and protection of the non-human athlete}

The pursuit of a sporting career is not just any profession. It demands strong aptitudes and outstanding skills, which cannot be attained through physical preparation alone. Animals employed in the sports business are qualified and specialized. They develop and enhance their abilities over the course of their professional careers. One is willing to pay a high price to have a particularly successful racehorse or one with auspicious pedigree - that is, one from 'champion' parents - join one's stalls.

\footnotetext{
55 'EGAlim Bill', Loi n 2018-938 du 30 Octobre 2018 pour l'équilibre des relations commerciales dans le secteur agricole et alimentaire et une alimentation saine, durable et accessible à tous, Projet de Loi pour l'équilibre des relations commerciales dans le secteur agricole et alimentaire et une alimentation saine et durable, Article 13, available at :

https://www.legifrance.gouv.fr/affichLoiPreparation.do;jsessionid=40311C1C3FDB5DE06BC5DC62A5B5E155.tplgfr22s_1?idDoc ument=JORFDOLE000036562265\&type=contenu\&id=2\&typeLoi=proj\&legislature=15 [Accessed 10 Dec. 2018].

${ }^{56}$ As sought by abolitionist movements.

${ }^{57}$ In France, Law of 2 July 1850 known as the Grammont Law on the ill-treatment of domestic animals. Recueil Duvergier, p299, available at: https:/www.legifrance.gouv.fr/affichTexte.do?cidTexte=JORFTEXT000000332380\&categorieLien=id [Accessed 10 Dec. 2018].

58 The Civil Code did not devote any chapter and, until 1978, did not even expressly contain any article on corporate legal personality. A first judgment conferred legal personality to civil societies, see Court of Cassation, req. 23-02-1891. A second provided for the attribution of legal personality to works councils, see Court of Cassation, 2nd civ., 28-01-1954.

59 The interest of the society is indeed distinct from that of its members, although it is an abstraction. 
However, the granting of a sportsperson's status to athlete animals is jealously guarded. Having an identical career, the privilege of being considered as a full-fledged 'sportsperson' is reserved for humans. Pursuant to Article L230-3 of the French Sports Code, the definition of a sportsperson reads as follows 'Any person who participates or trains: $1^{\circ}$ Either to a sports event organized by a federation certified or authorized by a delegated federation; $2^{\circ}$ Or to a sports event giving rise to an award in cash or kind, even though it is not organized by a federation certified or authorized by a delegated federation; $3^{\circ}$ Or to an international sports event.'

There is no certainty as to the correct interpretation of the term 'person' and its scope here. Has the legislator knowingly excluded the animal from the claim to the status of sportsperson? In any event, the animal involved has been bred and trained solely for the purpose of taking part in sports competitions. As a consequence, any animal that meets these conditions and pursues a sporting career should be considered as an athlete and granted adequate protection. It is therefore worth considering whether this controversial term dictates the benefit of this regime for the animal or whether it can be overlooked to accommodate a more inclusive interpretation of the 'sportsperson' to protect them all, whatever their species.

It is a critical issue, because by characterizing the nature of the relationships maintained between men and animals and by classifying the uses that are made of them, rights to protection are derived. The rules governing the sake of a particular animal are based on the legal status it is endowed with. Thus, in the absence of formal recognition that some animals can pursue a sporting career and that by doing so, they become a source of remuneration for the company, Chapter 1 of Title III of the French Sports Code, 'Santé des Sportifs et Lutte contre le Dopage' concerning the medical supervision of athletes, excludes from its scope of application those animals kept and trained for participation in sporting events, purely because they are not human beings, and although they also meet the eligibility conditions for being considered as athletes under this article. Athlete animals are also concerned by provisions relating to the fight against doping specific to them, duplicating provisions to ensure that no one regime can be admitted for both humans and animals when they are placed in the same situation.

Under the terms of Article L231-5 indeed, sports federations are for the moment responsible only for the health of their 'license holders' ${ }^{60}$, with the exception of the animals they use that obviously are not in the capacity to hold any. Medical check-ups are also scheduled on a regular basis for high-level human athletes only, pursuant to Article L231-6, leaving it to the federations to organize them. Thus, no veterinary monitoring or certification for the practice of a sport is mandatory for the admission of animals to participate in the competition. Only some exclusions aimed at maintaining a 'clean sport' temporarily exclude certain competitors so as not to give them an unfair advantage, in particular when they have been receiving certain drug treatments or have been suspended or punished in the event of suspicion or a proven case of doping.

No provisions relating to the protection of the health and welfare of animals used in sport, whether practiced at a professional or amateur level, have yet been included in the French Sports Code. Such inclusion would, however, be both legitimate and justified by means of the introduction of an obligation to monitor the health and welfare of these animals, in particular by recording veterinary acts and drug prescriptions, as well as the animal's general physical and mental condition. This obligation would make it possible to pursue not only the end of the protection of animal welfare, which is already legally protected, but also and beyond the general interest in terms of health (zoonoses and food safety), moral (fight against doping and corruption) and social (society's concern about the treatment of animals and fight against animal abuse) concerns.

Until the animal whose career consists in taking part in sporting and lucrative activities on behalf of the company is considered on an equivalent footing with the sporting 'human person' to be awarded a decent amount of protection, it would be advisable:

- To concede to those animals used by sports companies for the purpose of profit a technical legal personality commanding either the rewriting of some of the provisions of the French Sports Code, to specify by the addition of the terms 'human' or 'animal' those applicable to each of them, or the admission of a common athlete status that is not dependent on their quality as human or animal, subject to a list of provisions specifically applicable to human beings for obvious practical reasons.

- To insert a section guided by a philosophy of protecting the welfare and monitoring the health of all athletes, in particular at the highest level, with a view to granting its application to 'non-human athletes', along the lines of the single chapter inserted in Title IV concerning the fight against animal doping, after Title III 'Sportspersons' health and anti-doping control' of the French Sports Code.

- To include working animals in the company's 'non-human workforce', rather than downgrading the animal to the status of just any good of the company whose disposal is not adequately and effectively

${ }^{60}$ That is, to the health of human athletes, professional or amateur, who are involved in a sporting discipline. 
supervised to combat the precariousness and vulnerability of the animal worker or athlete at the moment.

\section{Conclusion}

Animal athletes used by sports companies benefit from the application of certain anti-doping provisions yet are excluded from the monitoring and protection of the health and welfare of sportspersons, which is reserved for human beings. Either the basis for such discrimination is speciesist, that is, establishes a difference of treatment based solely on species membership and, therefore, unfair because it hinders the protection of the animal in the practice of a risky and lucrative sports activity, or it is neglect. In both cases, it is an anomaly that must be rectified in law.

The adoption of standards and their consolidation in the sphere of Sports Law have undeniably improved the conditions under which horses are used by the sports company, by regulating many aspects of their training and participation in sporting events, well beyond the minimum standards surrounding the keeping of a domestic animal. A dual legal mechanism of administrative and criminal sanctions has been established to put an end to animal abuse, while in society a culture of fostering the conditions necessary for the welfare of animals has emerged, manifesting on all levels an 'Animal Turn' ${ }^{\text {'1 }}$. However, a general regime governing the use of animals by companies is lacking in the legal arsenal to address the current vulnerability of animals, which cannot be reduced to the fight against cruelty to animals, primarily targeting companion animals. Other animals used in sport are ignored, while even the fortunate members of the equine species remain largely under-protected. The scope of this protection is moreover mainly the result of self-regulation by sports federations and companies. Much remains to be done to shape and reform Animal Law.

All the consequences of the removal of animals from the legal category of things ${ }^{62}$ have not yet been drawn, either by European Union Law and its production-driven conception of sentient beings or by French Law paralyzed by a bipartite division between Things and Persons, unable to decide on the status to be granted to animals. The next stage of the Animal Turn will undoubtedly be the inclusion of animals in the study of the sociological, economic and legal phenomenon of work. The debate in terms of social justice will have to resolve the thorny question of the attribution of legal personality and, if so, the fundamental rights to be granted to domestic animals, which would be overlaid with rights specific to the situation in which they are individually placed or used by humans. Research, both scientific and legal, removes one by one the prejudices traditionally held against these advances, to overcome the obstacles to a reasoned and enlightened treatment of animals in the 21 st century.

Ultimately, businesses that use animals may well operate as true vectors of animal liberation, not in the radical sense of the word, but in the sense of removing the obstacles that are still stubbornly placed in the way of animals' personal development, as they provide a service to the community or the individual, enabling them to finally emancipate themselves. The main problem will lie in the qualification and quantification of the wealth produced by the participation of animals in society and more particularly in the company, and their fair remuneration and redistribution towards their better protection.

\section{Cited bibliography}

\section{$\underline{\text { Legal sources }}$}

$\underline{\text { Legislation }}$

\section{International}

- The United Nations. (1948). Universal Declaration of Human Rights, available at : http://www.un.org/en/udhrbook/pdf/udhr_booklet_en_web.pdf [Accessed 10 Dec. 2018].

- International Agreement on Trotting Races. International Agreement on Trotting Races, European Trotting Union, 2018 Edition, available at

\footnotetext{
${ }^{61}$ RITVO H., On the Animal Turn, in Daedalus 136 (2007) 118-122

${ }^{62}$ Known as 'de-objectification' in English, or 'déchosification' in French.

Under the expression 'descosificación de los animales' in Spanish, Professor T. Giménez-Candela describes the shift in the legal status of animals in Europe and Latin America according to three variables or stages: feeling, dignity, personality.

GIMÉNEZ-CANDELA T., Dignidad, Sentiencia, Personalidad: relación jurídica humano-animal, in dA.Derecho Animal (Forum of Animal Law Studies) 9/2 (2018) 5-16 https://doi.org/10.5565/rev/da.346 [Accessed 10 Dec. 2018].

72 Derecho Animal. Forum of Animal Law Studies, vol. 10/1
} 
:https://inapp.org/sites/default/files/NORMATIVA/2018/Comunitaria/UE_Accord_international_sur les_courses_au trot_UET\%202018.pdf [Accessed 10 Dec. 2018].

- World Antidoping Code, World Antidoping Agency, 2015, available at : https://www.wadaama.org/sites/default/files/resources/files/wada-2015-world-anti-doping-code-fr.pdf [Accessed 10 Dec. 2018].

- World Organization for Animal Health (OIE). Terrestrial Animal Health Code, Twenty-seventh Edition, 2018, Volume I, ISBN 978-92-95108-61-5, available at : http://www.oie.int/en/standardsetting/terrestrial-code/access-online/[Accessed 10 Dec. 2018].

- FEI, 2018 Equine Prohibited Substances List, 2017, available at :https://inside.fei.org/sites/default/files/2018\%20Equine\%20Prohibited\%20Substances\%20List.pdf [Accessed 10 Dec. 2018].

- FEI Equine Anti-Doping and Controlled Medication Regulations, $2^{\text {nd }}$ edition effective 2018, 2017 , available at :

https://inside.fei.org/sites/default/files/2108\%20EADCMRs\%20\%20Effective\%201\%20January\%202018\%20-\%20Final\%20Version_clean.pdf [Accessed 10 Dec. 2018].

- The International Organization for Standardization (ISO). ISO 26000, Social Responsibility, available at :https://www.iso.org/fr/iso-26000-social-responsibility.html [Accessed 10 Dec. 2018].

\section{National}

- Law of 22 March 1841 on child labor in manufactures, factories or workshops, dite 'Loi Montalembert', available at: https://travail-emploi.gouv.fr/IMG/pdf/loi 22 mars 1841-2.pdf [Accessed 10 Dec. 2018].

- Law of 2 July 1850 on the ill-treatment of domestic animals, dite 'Loi Grammont'. Recueil Duvergier, p299, available at: https://www.legifrance.gouv.fr/affichTexte.do?cidTexte=JORFTEXT000000332380\&categorieLien= id [Accessed 10 Dec. 2018].

- Charter for Equine Welfare, signed in Paris on 4 March 2016, available at : http://www.lafranceagricole.fr/r/Publie/FA/p1/Infographies/Web/2016-03-07/CharteEquins.pdf [Accessed 10 Dec. 2018].

- Bulletin de la Société d'Encouragement à l'Élevage du Cheval Français. (2018) Règlement de la Société d'Encouragement à l'Élevage du Cheval Français formant le Code des Courses au Trot. Le Trot, available at : https://pro.letrot.com/siteletrotws/publication?type=CODECOURSE [Accessed 10 Dec. 2018].

- France Galop. (2018) Code des Courses au Galop, available at : http://www.francegalop.com/sites/default/files/18code09c.pdf [Accessed 10 Dec. 2018].

- EGALim Bill. Loi n ${ }^{\circ}$ 2018-938 du 30 octobre 2018 pour l'équilibre des relations commerciales dans le secteur agricole et alimentaire et une alimentation saine, durable et accessible à tous, Projet de loi pour l'équilibre des relations commerciales dans le secteur agricole et alimentaire et une alimentation saine et durable, available at: https://www.legifrance.gouv.fr/affichLoiPreparation.do;jsessionid=40311C1C3FDB5DE06BC5DC62 A5B5E155.tplgfr22s 1?idDocument=JORFDOLE000036562265\&type $=$ contenu\&id=2\&typeLoi $=$ pro j\&legislature $=15$ [Accessed 10 Dec. 2018].

- Code du Sport, Consolidated version as of November 30, 2018. Version as in force on December 10, 2018 , available https://www.legifrance.gouv.fr/affichCode.do?cidTexte=LEGITEXT000006071318 [Accessed 10 Dec. 2018].

- Code de l'Animal, Sous la direction de J.P. Marguénaud et de J. Leroy, LexisNexis, 1re édition, 2018, ISBN : 978-2-7110-2653-1, 1058p

- Code Civil. Consolidated version as of October 1, 2018. Version as in force on December 10, 2018, available at: https://www.legifrance.gouv.fr/affichCode.do?cidTexte=LEGITEXT000006070721 [Accessed 10 Dec. 2018].

- Code de la Consommation, Consolidated version as of November 25, 2018, available at: https://www.legifrance.gouv.fr/affichCode.do?cidTexte=LEGITEXT000006069565 [Accessed 10 Dec. 2018].

- Code Pénal. Consolidated version as of November 25, 2018. Version as in force on December 10, 
2018,

available

at: https://www.legifrance.gouv.fr/affichCode.do?cidTexte=LEGITEXT000006070719 [Accessed 10 Dec. 2018].

- Code Rural et de la Pêche Maritime. Consolidated version as of December 3, 2018. Version as in force on December 10, 2018, available at: https://www.legifrance.gouv.fr/affichCode.do?cidTexte=LEGITEXT000006071367 [Accessed 10 Dec. 2018].

French caselaw

- 'Lunus' judgment. Court of Cassation, Civil Chamber 1, 16 January 1962, Published in the bulletin.

- 'Delgado' judgment, Court of Cassation, Civil Chamber 1, 9 December 2015, 14-25.910, Published in the bulletin.

\section{Other sources}

$\underline{\text { Books }}$

- BOWEN H., Social Responsibilities of the Businessman (New York 1953).

- DONALDSON, S., KYMLICKA, W., Zoopolis: A political theory of animal rights (Oxford 2011).

- FRIEDMANN G., NAVILLE P., Traité de sociologie du travail (Paris 1962).

- VON UEXKÜLL J.., Mondes animaux et monde humain, suivi de Théorie de la signification (Paris 1965).

- ZOLA E., Germinal (Paris 1885).

$\underline{\text { Articles }}$

- FUREIX C. et al., Investigating anhedonia in a non-conventional species: Do some riding horses Equus caballus display symptoms of depression?, in Applied Animal Behaviour Science 162 (2015) 26-36

- FUREIX C., JEGO P., HENRY S., LANSADE L., HAUSBERGER M., Towards an Ethological Animal Model of Depression? A Study on Horses, in PLoS ONE 7(6) (2012) https://doi:10.1371/journal.pone.0039280 [Accessed 10 Dec. 2018].

- GIMÉNEZ-CANDELA T., Dignidad, Sentiencia, Personalidad: relación jurídica humano-animal, in dA.Derecho Animal (Forum of Animal Law Studies) 9/2 (2018) 5-16 https://doi.org/10.5565/rev/da.346 [Accessed 10 Dec. 2018].

- LE GAL, S., Surentraînement du cheval : quel peut être l'apport du suivi de la leptinémie ? Thèse d'exercice, Médecine vétérinaire, Ecole Nationale Vétérinaire de Toulouse - ENVT (2012)

- RITVO H., On the Animal Turn, in Daedalus 136 (2007) 118-122

- SAAVEDRA J., Hannah Arendt y el "animal laborans". Reflexiones en torno a la condición humana postmoderna, in Nómadas. Revista Crítica de Ciencias Sociales y Jurídicas 29/1 (2011) http://dx.doi.org/10.5209/rev_NOMA.2011.v29.n1.267 [Accessed 10 Dec. 2018].

- TYLER-MCGOWAN C. M., GOLlAND L. C., EVANS D. L., HODGSON D. R., ROSE R. J., Hematological and biochemical responses to training and overtraining, in Equine Veterinarian Journal 30 (1999) 621-625.

\section{$\underline{\text { Documents }}$}

- Observatoire des jeux (2018). Données d'activité Pari Mutuel Urbain (PMU). [online] Le portail des ministères économiques et financiers, available at:

- https://www.economie.gouv.fr/observatoire-des-jeux/donnees-dactivite-pari-mutuel-urbain-pmu [Accessed 10 Dec. 2018].

- Elior Group, Positive Foodprint Plan, available at: https://www.eliorgroup.com/fr/elior-grouppositive-foodprint-plan [Accessed 10 Dec. 2018].

Online Press 
- 'Pets at work ou les bienfaits des animaux au bureau', GA Smart Building, October 17, 2016, available at : https://www.ga.fr/newsroom/pets-work-ou-les-bienfaits-des-animaux-au-bureau [Accessed 10 Dec. 2018].

- 'Le statut de l'animal est en lévitation juridique', Terre d'Actu, November 18, 2016, available at : http://www.terredactu.com/entretien-jean-pierre-marguenaud.html [Accessed 10 Dec. 2018].

- 'Les animaux consentent-ils à travailler ?', Le Monde, January 7, 2018, available at: https://www.lemonde.fr/idees/article/2018/01/07/les-animaux-consentent-ils-atravailler 5238389 3232.html [Accessed 10 Dec. 2018].

- 'Chiens et chats dans l'open space', L'Express Entreprise, June 10, 2018, available at: https://lentreprise.lexpress.fr/des-chiens-et-des-chats-dans-1-open-space_2010594.html [Accessed 10 Dec. 2018].

- 'GB: Burberry renounces fur and the destruction of unsold goods', Fondation 30 Millions d'Amis, September 6, 2018, available at: https://www.30millionsdamis.fr/actualites/article/14462-gb-burberryrenonce-a-la-fourrure-et-a-la-destruction-des-invendus/. [Accessed 10 Dec. 2018].

- 'La Fashion Week de Londres défilera sans fourrure cette année', Madmoizelle, September 10, 2018 , available at: http://www.madmoizelle.com/fashion-week-londres-sans-fourrure-952242 [Accessed 10 Dec. 2018]. 